Хаврук В.О.

Національний транспортний університет, Київ, Украӥна

\title{
ВПЛИВ ТЕХНІКО-ЕКСПЛУАТАЦЙНИХ ВЛАСТИВОСТЕЙ ВАНТАЖНИХ АВТОМОБІЛІВ НА ПОКАЗНИКИ ЕФЕКТИВНОСТІ ЕКСПЛУАТАЦІї
}

\begin{abstract}
У роботі розглядаються комплексні показники, за якими оцінюється ефективність експлуатації рухомого складу - вантажних автомобілів: продуктивність, собівартість перевезень, коефіцієнт технічної готовності. 3'ясовано, що продуктивність визначається за певний період часу - розрізняють годинну, добову, місячну, квартальну, річну продуктивності. Наведені формули для визначення річної продуктивності враховують конструкцію, простої автомобіля в ремонтах і технічних обслуговуваннях. На основі аналізу встановлено, що річна продуктивність вантажних автомобілів залежить від техніко-експлуатаційних властивостей, які включають дві групи параметрів: 1) пов'язані з конструкцією автомобіля (середня технічна швидкість, вантажопідйомність); 2) не пов'язані з конструкцією автомобіля (кількість днів роботи в році, час знаходження автомобіля в наряді в добу, середня довжина їзди з вантажем, коефіцієнт використання пробігу). Досліджено вплив вантажопідйомності автомобіля на продуктивність і доведено, що продуктивність зростає 3 підвищення вантажопідйомності автомобіля і зменшується зі збільшенням відстані їзди з вантажем. На основі залежності собівартості транспортування вантажу для автомобілів самоскидів і вантажівок загального призначення показано, що із збільшенням вантажопідйомності автомобіля собівартість знижується. Обгрунтовано доцільність використання на коротких відстанях малотоннажних автомобілів, оскільки за таких умов спрощуються процеси навантаження і розвантаження, маневрування автомобілів, як результат знижуються витрати на паливо-мастильні матеріали, навантажувально-розвантажувальні роботи. Аналіз цієї залежності дозволив встановити, що на коротких відстанях використання малотоннажних автомобілів вигідніше, оскільки спрощуються умови вантаження і розвантаження, спрощується маневрування автомобілів, а отже знижуються витрати на паливо, навантажувально-розвантажувальні роботи. Але ця залежність була отримана для специфічних умов експлуатації при організації роботи автотранспорту на відкритих розробках. Можливість повного використання вантажопідйомності автомобіля охарактеризовано за допомогою коефіцієнта використання вантажопідйомності. Встановлено, що між продуктивністю і коефіцієнтом використання вантажопідйомності існує пряма пропорційна залежність, при цьому, конструктивні особливості автомобіля характеризуються трьома експлуатаційними властивостями: швидкість руху, прохідність $\mathrm{i}$ надійність автомобіля. 3'ясована залежність продуктивності деяких вантажних автомобілів і собівартості транспортування вантажу від середньої технічної швидкості. Коефіцієнт технічної готовності переставлений як комплексний показник, який характеризує такі властивості надійності, як: безвідмовність, ремонтопридатність і довговічність та враховує простої в усіх видах технічного обслуговування і ремонтах. з'ясовано, що між продуктивністю на певному пробігу і собівартістю перевезень існує прямо пропорційний зв'язок - чим вища продуктивність тим нижча собівартість перевезень і навпаки.

Ключові слова: вантажний автомобіль, коефіцієнт технічної готовності, продуктивність, простій, рухомий склад, собівартість перевезень, техніко-експлуатаційні властивості.
\end{abstract}

\section{ВСТУП}

Ефективність експлуатації автомобілів при здійсненні вантажних комерційних перевезень для власника рухомого складу (РС) в кінцевому підсумку визначається отриманням якомога більшого прибутку. Величина, отримуваного прибутку, залежить від ефективності використання автомобілів і собівартості перевезення вантажу, що в свою чергу залежать від величини експлуатаційних витрат. Таким чином, техніко-експлуатаційні властивості РС мають безпосередній вплив на показники ефективності експлуатації.

\section{АНАЛІЗ ЛІТЕРАТУРНИХ ДАНИХ ТА ПОСТАНОВКА ПРОБЛЕМИ}

Проблема підвищення ефективності експлуатації автомобілів $\epsilon$ досить важливою, яку досліджують, зокрема, такі науковці, як: Бачурин О.О., Бичков В.П., Бочкарьова М.М., Гудков В.О., Мигачов В.А., Пеньшин Н.В., Резник Л.Г., Фасхієв А.Х.

В роботах авторів, дослідження проблеми підвищення ефективності експлуатації автомобілів здійснюється або через аналіз і розрахунок загальних показників виробничо-господарської діяльності автопідприємства [1; 2], або через кількісну оцінку якості транспортних послуг [3; 4]. Більш послідовне і комплексне дослідження проблеми ефективності експлуатації РС на прикладі вантажних автомобілів здійснив в дисертаційній роботі Мигачов В.А. [5], розглянувши як загальні фактори і тенденції, які впливають на експлуатацію вантажних автомобілів, так і обгрунтувавши показники, за якими доцільно здійснювати оцінку ефективності експлуатації безпосередньо на автопідприємствах 3 наявними РС. 
Нині в Україні парк вантажних автомобілів комерційного призначення оновлюється за рахунок сучасних моделей ближнього зарубіжжя (ГАЗ, МАЗ, КамАЗ) та відомих виробників вартажівок (DAF, Iveco, MAN, Mercedes, Scania, Volvo та ін.). При цьому власники автотранспортних підприємств здійснюють вибір автомобілів, орієнтуючись на престиж марки, наявність тих або інших моделей на ринку, їх вартість і т.д. Але в процесі експлуатації виявляється, що придбаний автомобіль має великі в порівнянні $з$ конкурентами експлуатаційні витрати, хоча і відповідає вимогам технологічного процесу перевезень. У більшості випадків це пов'язано або з відмовами автомобілів або з високою вартістю запасних частин, витратних і мастильних матеріалів. За таких умов, для суб'єктів підприємницької діяльності, які надають послуги з перевезення вантажів, актуальним питанням $\epsilon$ аналіз та оцінка ефективності використання (експлуатації) наявного РС.

Крім того, беручи до уваги, що існує багато методів оцінки ефективності експлуатації РС, постає необхідність у додатковому дослідженні даної проблематики, зокрема в обгрунтуванні показників, за якими можливо здійснити оцінку ефективності експлуатації РС на автотранспортному підприємстві.

\section{ЦІЛЬ ТА ЗАДАЧІ ДОСЛІДЖЕННЯ}

Основною метою дослідження $є$ з'ясування основних техніко-експлуатаційних властивостей (TEB) вантажних автомобілів, які впливають на показники ефективності експлуатації, а також встановити взаємозв'язок між ними.

\section{РЕЗУЛЬТАТИ ДОСЛІДЖЕНЬ}

Основними показниками ефективності експлуатації вантажних автомобілів є: продуктивність, собівартість перевезень, коефіцієнт технічної готовності.

Розглянемо формули річної продуктивності, оскільки в них враховуються залежності від конструкції простої автомобіля в ремонтах і технічних обслуговуваннях (ТО), які у формулах годинної або добової продуктивності відсутні. Для вантажних автомобілів залежність має наступний вигляд [5, с. 25; 6]:

$$
W_{B}=\frac{q \cdot \gamma \cdot \beta \cdot \mathrm{v}_{T} \cdot T \cdot D \cdot \alpha}{l+\beta \cdot v_{T} \cdot t_{\Pi P}},
$$

де $\mathrm{v}_{T}-$ середня технічна швидкість, км/год.;

$q$ - вантажопідйомність, т;

$\gamma$ - коефіцієнт використання вантажопідйомності;

$l$ - середня довжина їзди з вантажем, км;

$\beta$ - коефіцієнт використання пробігу;

$t_{\Pi P}-$ час простою під завантаженням і вивантаженням за одну їзду, год.;

$T$ - час роботи в добу, год.;

$D$ - кількість днів роботи в році;

$\alpha$ - коефіцієнт використання автомобіля за рік.

Залежність (1) дозволяє встановити взаємозв'язок між конструктивними особливостями i продуктивністю автомобіля, який характеризується окремими техніко-експлуатаційними властивостями. Тут можуть бути виділені параметри, не пов'язані з конструкцією автомобіля. До них відносяться: кількість днів роботи в році $D$; час знаходження автомобіля в наряді в добу $T$; середня довжина їзди 3 вантажем $l$; коефіцієнт використання пробігу $\beta$. Ці параметри можна виділити в постійні величини, позначивши їх через $a$ з відповідним індексом $\left(a_{B}\right)$. Тоді функціональну залежність продуктивності від параметрів, які визначаються конструкцією автомобіля, можна виразити в наступному загальному вигляді $[5$, с. 26]:

$$
W_{B}=a_{B} \cdot f\left(q, \gamma, \mathrm{v}_{T}, t_{\Pi P}, \alpha\right)
$$

Усі параметри в дужках залежності (2) в тій чи іншій мірі залежать від конструкції автомобіля. Для кожного з них можна встановити техніко-експлуатаційні властивості, що дозволяють оцінювати особливості конструкції автомобіля, що впливають на ефективність його експлуатації.

Вантажопідйомність автомобіля визначається конструктивною розмірністю і міцністю основних вузлів, що несуть, і агрегатів його шасі: рами мостів, підвіски, коліс, шин та ін. При обмеженні дорожніми нормами повної маси автомобіля вантажопідйомність залежить від власної його маси: чим вона менша, тим відповідно більше вантажопідйомність. Вплив вантажопідйомності автомобіля на продуктивність (рис. 1) показує, що продуктивність зростає 3 підвищення вантажопідйомності автомобіля і зменшується зі збільшенням відстані їзди з вантажем [7]. 


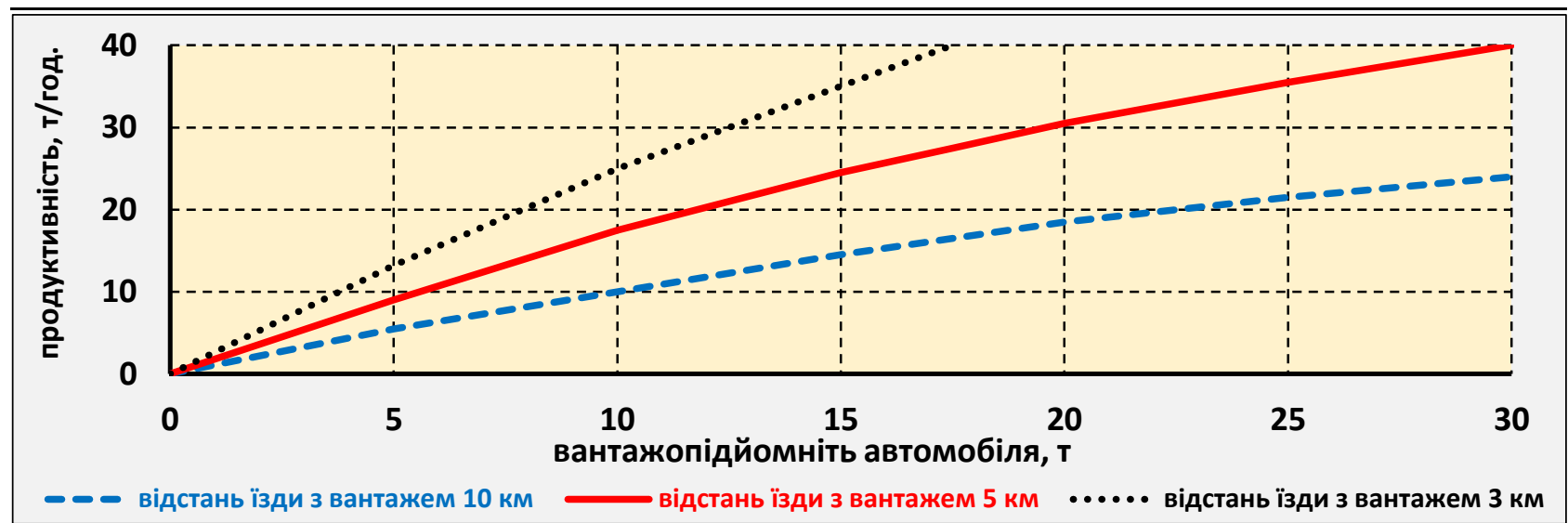

Рисунок 1 - Залежність продуктивності автомобіля від вантажопідйомності

Але 3 підвищенням вантажопідйомності автомобіля підвищується абсолютна металоємність перевезень, витрата палива (оскільки зростає потужність двигуна), збільшується навантаження на дорожнє полотно і т.д. Але встановлені залежності собівартості транспортування вантажу для автомобілів самоскидів і вантажівок загального призначення рис. 2, рис. 3) показують, що із збільшенням вантажопідйомності автомобіля собівартість знижується [7].

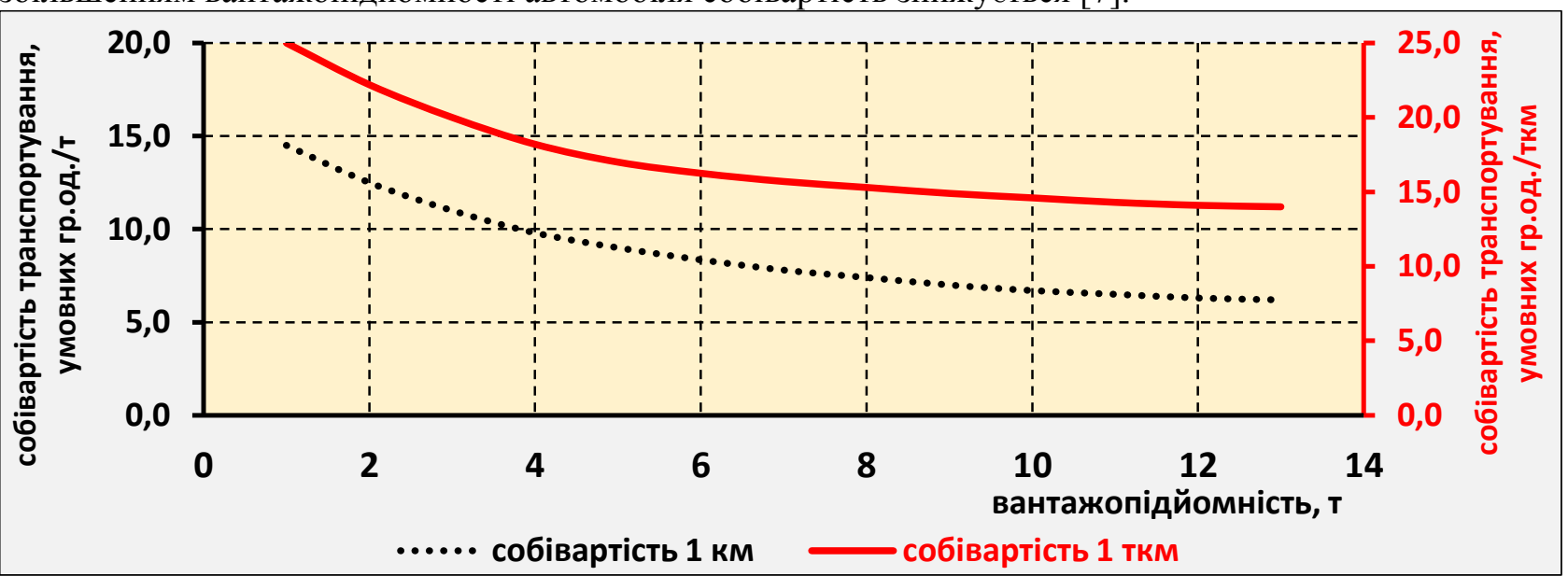

Рисунок 2 - Залежність собівартості транспортування в залежності від вантажопідйомності автомобілів-самоскидів

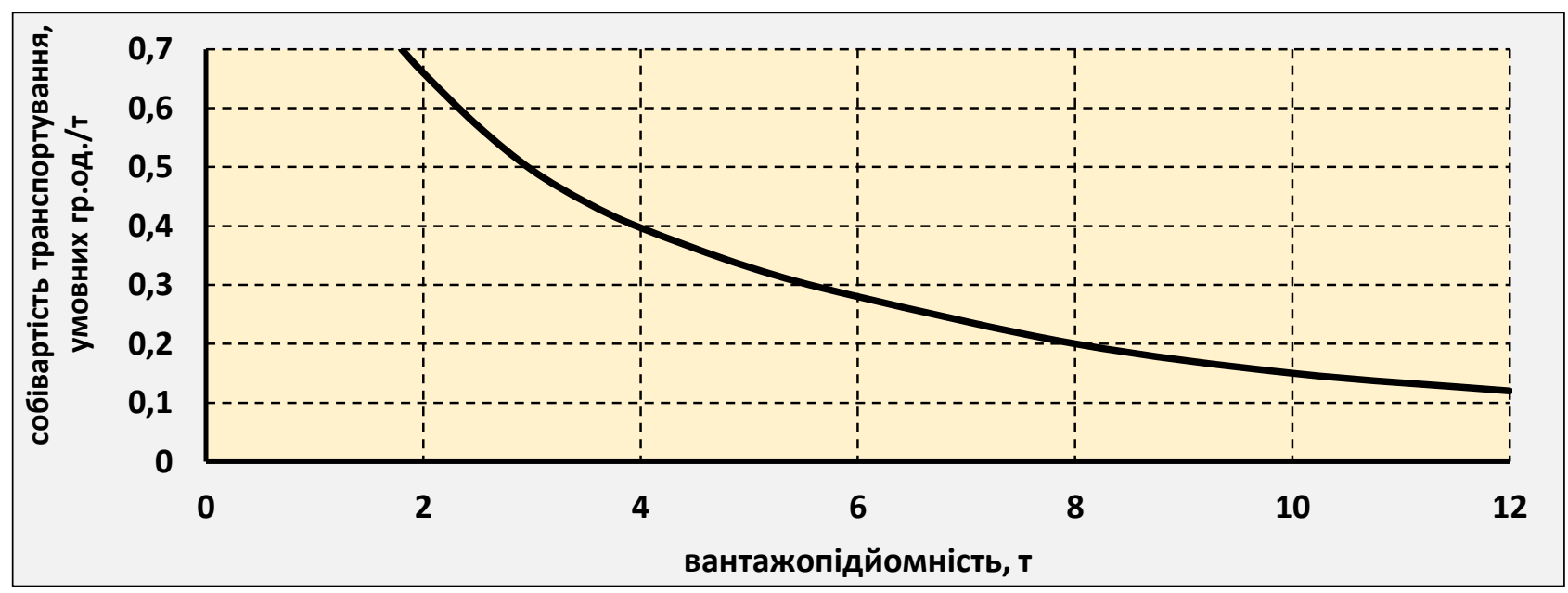

Рисунок 3 - Залежність собівартості транспортування від вантажопідйомності вантажних автомобілів загального призначення 


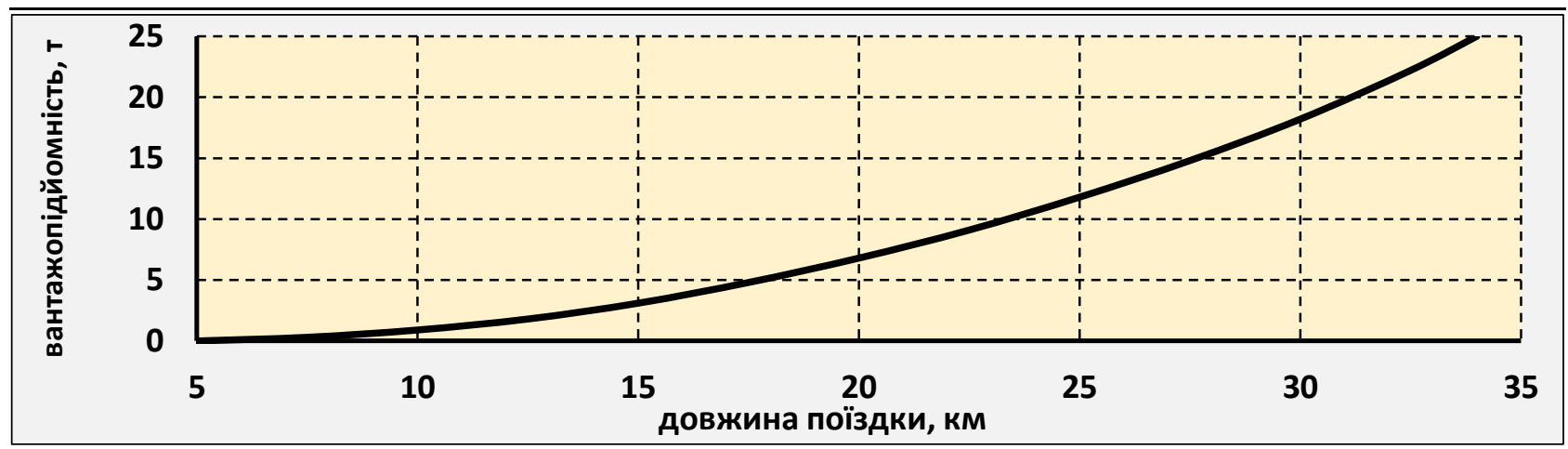

Рисунок 4 - Залежність вантажопідйомності автомобілів-самоскидів від відстані перевезень

Виконані розрахунки за порівняльною економічною оцінкою застосування різних видів транспорту дозволили встановити залежність раціональної вантажопідйомності автомобілів самоскидів від відстані поїздки з вантажем (рис. 4). Аналіз цієї залежності дозволив встановити, що на коротких відстанях використання малотоннажних автомобілів вигідніше, оскільки спрощуються умови навантаження і розвантаження, спрощується маневрування автомобілів, а отже знижуються витрати на паливо, навантажувально-розвантажувальні роботи. Але ця залежність була отримана для специфічних умов експлуатації при організації роботи автотранспорту на відкритих розробках. Застосування ії для аналізу роботи вантажних автомобілів для дальніх поїздок неприйнятне.

Можливість повністю використати вантажопідйомність автомобіля залежить від внутрішніх розмірів кузова і об'ємної маси вантажу. Це потребує врахування другого параметра у формулі продуктивності - коефіцієнта використання вантажопідйомності $\gamma$. Величина його може залежати не лише від розмірів кузова, але в деяких випадках від інших особливостей його конструкції. Залежність продуктивності вантажного автомобіля від коефіцієнта використання вантажопідйомності представлена на рис. 5 [7].

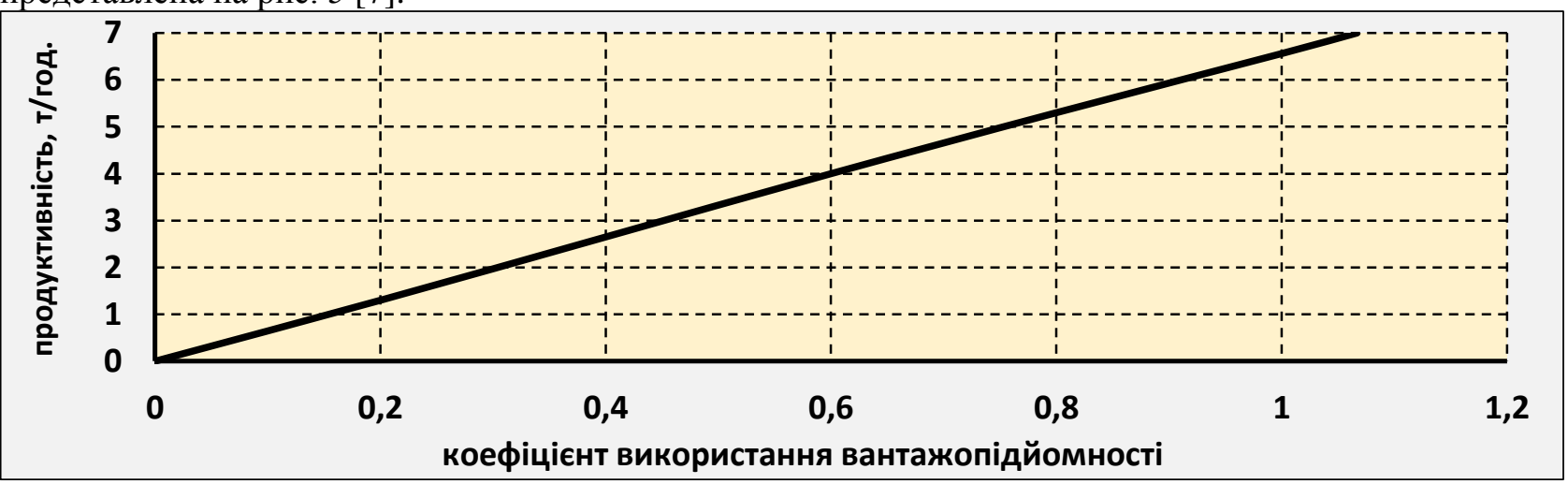

Рисунок 5 - Залежність продуктивності автомобіля від коефіцієнта використання вантажопідйомності

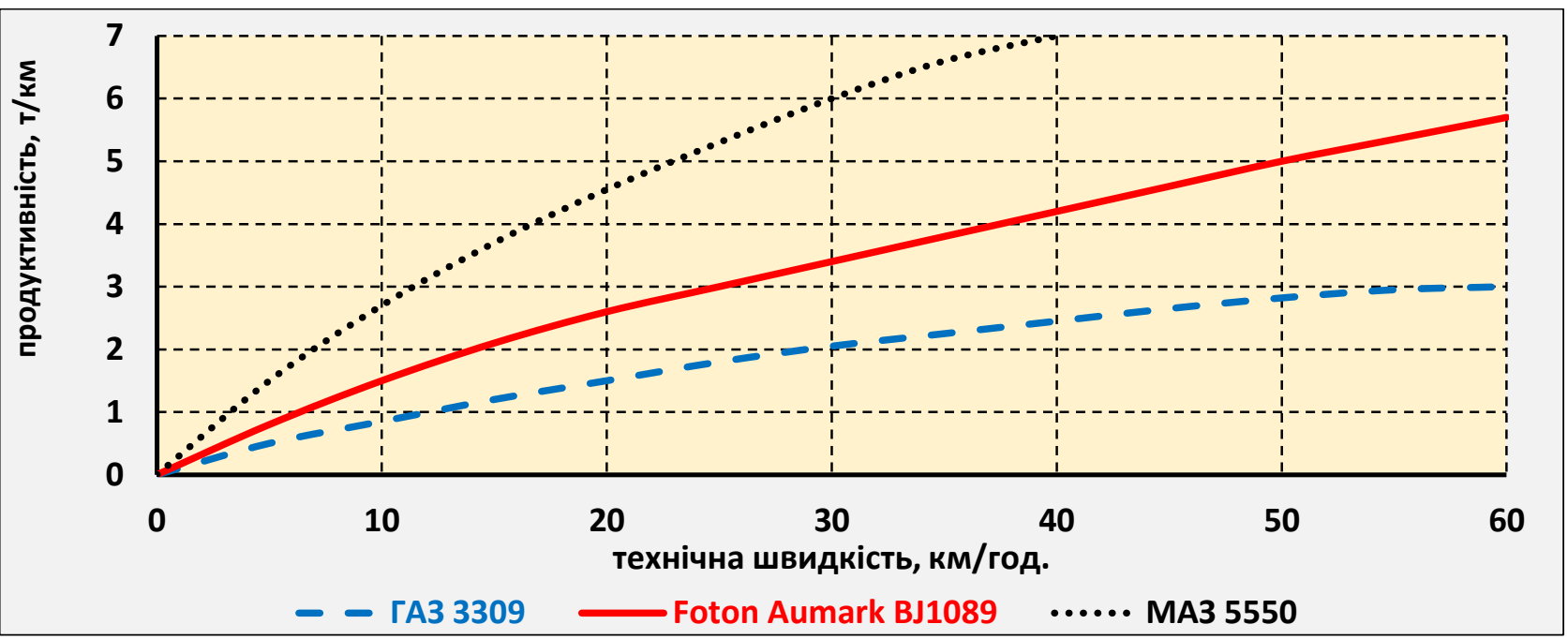

Рисунок 6 - Залежність продуктивності деяких автомобілів від технічної швидкості 
Як видно 3 рис. 5 продуктивність пропорційно залежить від коефіцієнта використання вантажопідйомності, отже на цей показник не впливають інші змінні величини у формулі (2). Вантажопідйомність автомобіля у поєднанні з можливим коефіцієнтом використання при перевезенні вантажу, що визначається об'ємною масою і характеризується експлуатаційною якістю, називається місткістю автомобіля. Залежність продуктивності деяких вантажних автомобілів і собівартості транспортування вантажу від середньої технічної швидкості $\left(\mathrm{v}_{T}\right)$ представлена на рис. 6, рис. 7.

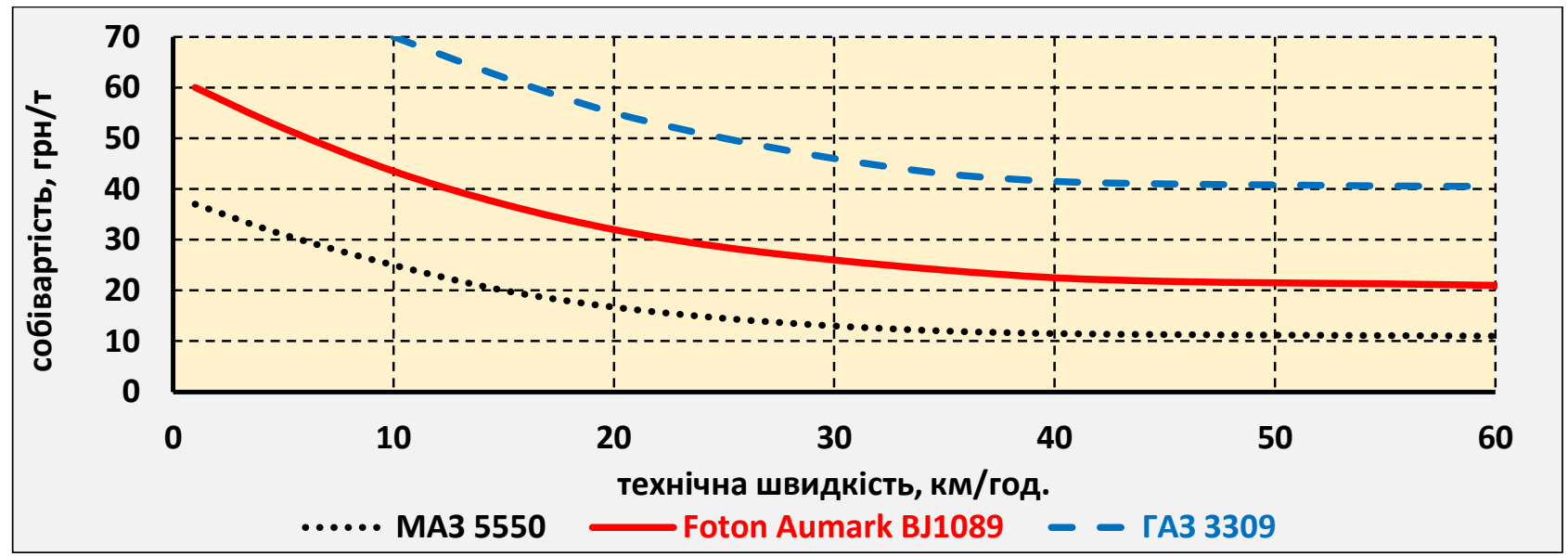

Рисунок 7 - Залежність собівартості транспортування вантажу від технічної швидкості

Технічна швидкість визначається як шлях, пройдений автомобілем за сумарний час руху і простоїв на лінії через несправності автомобіля і їх усунення [6; 7]. Тому вона безпосередньо залежить від міцності і надійності деталей основних вузлів автомобіля, пускових якостей двигуна, безвідмовності систем і механізмів автомобіля. Це багато в чому визначається конструкцією автомобіля і здатністю автотранспортного підприємства підтримувати його в працездатному стані [8; 9].

Таким чином, технічна швидкість падає зі зниженням надійності автомобіля і його агрегатів, отже, знижується продуктивність, а собівартість транспортування підвищується. Надійність автомобілів багато в чому залежить від режимів його роботи. Технічна швидкість автомобіля також залежить: від потужності двигуна, повної маси автомобіля, передаточного числа трансмісії, іiі коефіцієнта корисної дії, радіусу кочення ведучих коліс, величини опору коченню автомобіля $\mathrm{i}$ аеродинамічного опору руху. Середня технічна швидкість залежить від роботи гальмівних механізмів автомобіля і параметрів, що визначають його стійкість і керованість, оглядовість дороги в денний і нічний час, а також параметрів підвіски, маневреності і ряду інших особливостей конструкції. Наприклад, встановлена залежність середньотехнічної швидкості від типу покриття (табл. 1) [9].

Таблиця 1 - Вплив типу покриття на середньотехнічну швидкість автомобіля [9]

\begin{tabular}{|l|c|c|c|c|c|}
\hline \multirow{2}{*}{ Параметр } & \multicolumn{5}{|c|}{ Тип дорожнього покриття } \\
\cline { 2 - 6 } & $\begin{array}{c}\text { Цементобетон, } \\
\text { асфальтобетон }\end{array}$ & $\begin{array}{c}\text { Бітумно-мінеральні } \\
\text { суміші }\end{array}$ & $\begin{array}{c}\text { Щебінь, } \\
\text { гравій }\end{array}$ & $\begin{array}{c}\text { Кругляк, грунт } \\
\text { укріплений }\end{array}$ & $\begin{array}{c}\text { Звичайний } \\
\text { грунт }\end{array}$ \\
\hline Коефіцієнт опору & 0,014 & 0,020 & 0,032 & 0,040 & 0,080 \\
\hline $\begin{array}{l}\text { Середньотехнічна } \\
\text { швидкість }\end{array}$ & 66 & 56 & 36 & 27 & 20 \\
\hline
\end{tabular}

Отже, чим більшу надійність, довговічність шин, ремонтопридатність в дорожніх умовах, запас потужності двигуна і кращу прохідність має автомобіль, тим більшу технічну швидкість він матиме при транспортуванні вантажів, а отже і більшу продуктивність.

Таким чином, проаналізовані конструктивні особливості автомобіля характеризуються наступними трьома експлуатаційними властивостями: швидкість руху, прохідність і надійність автомобіля.

Час простою під вантаженням і вивантаженням $t_{\Pi P}$ може залежати від конструкції кузова, навантажувальної висоти кузова, конструкції бортів або у випадку кузова-фургона від розмірів дверей, їх розташування, наявності і ефективності дії різних механізмів і спеціальних пристроїв для 
полегшення вантаження i вивантаження (пристроїв самоскидів, навантажувачів та ін.). Продуктивність вантажного автомобіля від часу навантаження-розвантаження представлена на рис. 8 [9].

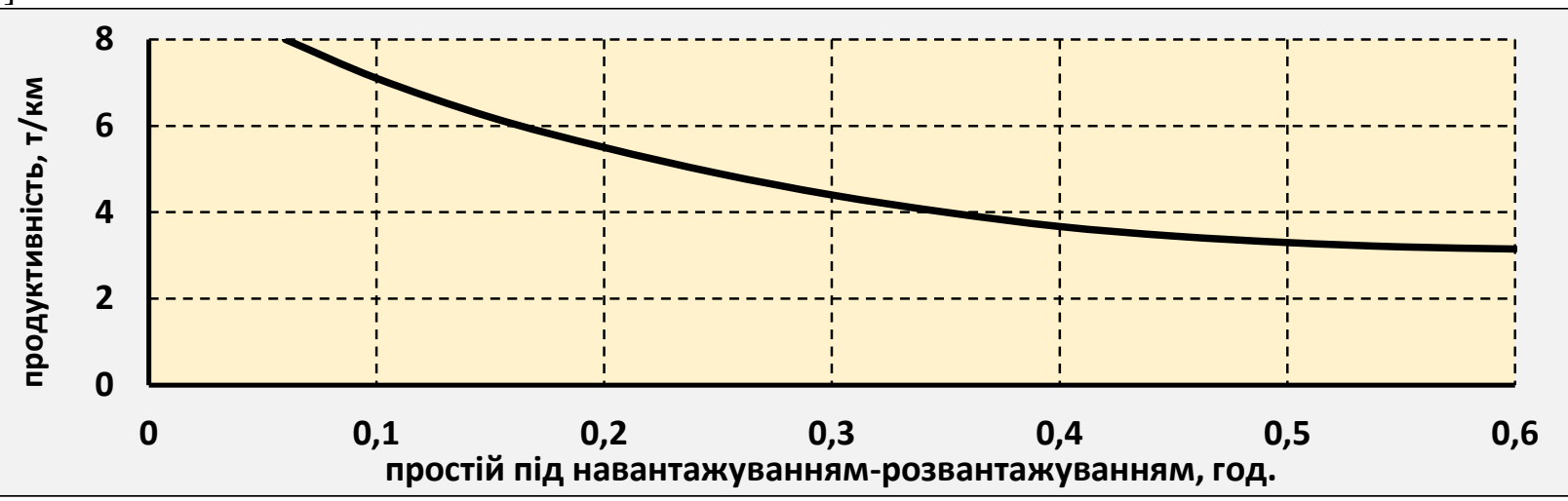

Рисунок 8 - Залежність продуктивності автомобіля від часу навантаження-розвантаження

Цей час також залежить від маневреності автомобіля, що характеризується мінімальним радіусом повороту, габаритним коридором, простотою керування при русі заднім ходом. Вказані особливості конструкції автомобіля характеризуються експлуатаційною якістю, що називається зручністю використання автомобіля.

Коефіцієнт технічної готовності $\alpha_{T}$ характеризує такі властивості надійності, як: безвідмовність, ремонтопридатність і довговічність. В цьому випадку, чим менше відмов у автомобілів, тим нижча трудомісткість обслуговування і ремонту, вищий середній ресурс автомобіля до ремонту, тим вищий $\alpha_{T}$ за інших рівних умов. Вплив показників надійності на $\alpha_{T}$ і продуктивність автомобіля має наступну логічну послідовність [5, с. 33]:

$$
\left(\Delta L_{\Pi P}, \Delta t_{\Pi P}\right) \rightarrow \Delta B_{P} \rightarrow \Delta \alpha_{T} \rightarrow \Delta \alpha_{B} \rightarrow \Delta W,
$$

де $\Delta L_{\Pi P}$ - зміна середнього напрацювання на відмову, км;

$\Delta t_{\Pi Р}-$ зміна тривалості простою в робочий час автомобіля, год.;

$\Delta B_{P}$ - зміна питомих простоїв з втратою робочого часу за цикл автомобіля в усіх видах ТО і ремонту, днів/1000 км;

$\Delta \alpha_{B}-$ зміна коефіцієнта випуску автомобілів;

$\Delta W$ - зміна продуктивності автомобілів, ткм.

Встановлений взаємозв'язок $\alpha_{T} 3$ конкретними показниками надійності автомобілів, тобто 3 напрацюванням на випадок простою $L_{\Pi P i}$ і тривалості простою $t_{\Pi P i}[5$, c. $34 ; 8]$ :

$$
\alpha_{T}=\frac{1}{1+l_{C C} \cdot \frac{\bar{t}_{\Pi P}}{L_{\Pi P}}}=\frac{1}{1+l_{C C} \cdot B_{P}}-\frac{1}{1+l_{C C} \cdot \bar{t}_{\Pi P} \cdot \omega_{\Pi P}},
$$

де $\omega_{\Pi P}-$ параметр потоку відмов, що викликали простій автомобіля з втратою робочого часу;

$\bar{t}_{\Pi P}-$ середня тривалість простою в робочий час автомобіля, год.;

$B_{P}$ - питомі простої з втратою робочого часу за цикл автомобіля в усіх видах ТО і ремонтах, днів/1000 км;

$l_{C C}$ - середньодобовий пробіг, що характеризує умови та інтенсивність експлуатації автомобілів, км.

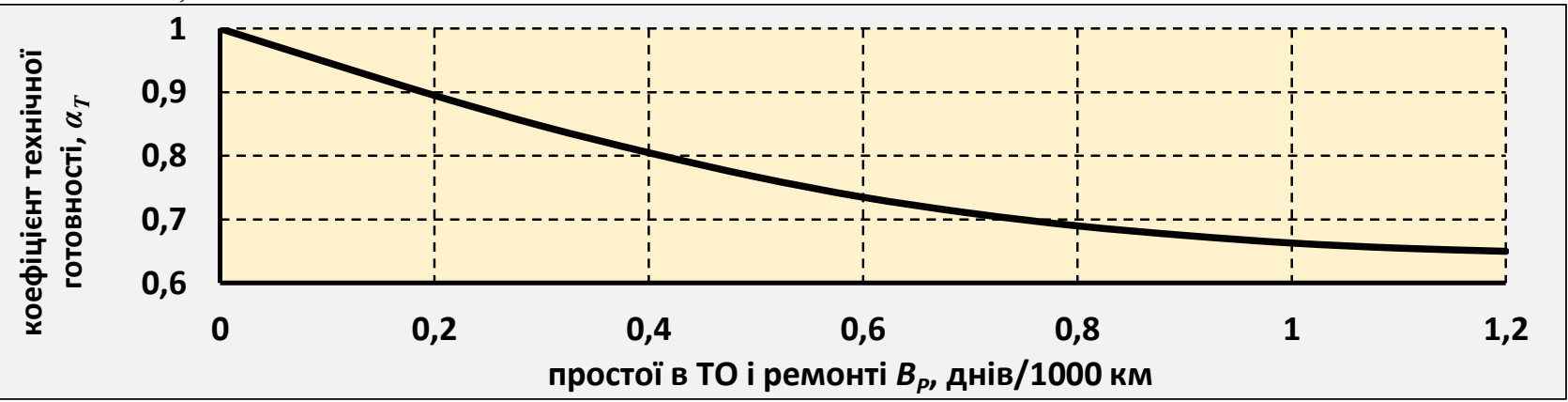

Рисунок 9 - Вплив простоїв в ТО і ремонті на коефіцієнт технічної готовності 
Середня тривалість простою в робочий час автомобіля $\bar{t}_{\Pi P}$ (коли усувається відмова або несправність) характеризує рівень технології і організації виробництва, а також пристосованість автомобіля і його агрегатів до ТО і ремонту, тобто експлуатаційну технологічність Залежність тривалості простою в ТО і ремонті на величину $\alpha_{T}$ представлена на рис. 9 [9].

Середнє напрацювання на відмову визначається надійністю автомобіля, умовами експлуатації, а також якістю проведення ТО і ремонту.

Системний зв'язок вказаних властивостей 3 розглянутими показниками ефективності експлуатації автомобілів дає змогу стверджувати, що на продуктивність автомобіля впливають його конструктивні особливості. Це пояснюється пристосованістю конструкції до перевезення певного виду вантажу максимально можливої маси (формула 1). Надійність автомобіля визначає його работоздатність, тобто саму можливість здійснення перевезень, таким чином, впливає на продуктивність. Експлуатаційна технологічність визначає час виконання робіт з ТО і ремонту а, отже, час вилучення автомобіля 3 лінії, що впливає на його продуктивність. Динамічність, стійкість, маневреність, легкість керування і комфортабельність автомобіля визначають величину часу навантаження-розвантаження i середньотехнічну швидкість, від яких залежить продуктивність автомобіля.

Оскільки собівартість перевезень вимірюється в питомих одиницях до обсягу виконаної транспортної роботи (грн/ткм), то тип і надійність автомобіля, безпосередньо впливають на собівартість перевезень. Чим вища продуктивність на певному пробігу, тим нижча собівартість перевезень. Експлуатаційна технологічність визначає трудомісткість підтримки автомобілів в працездатному стані, а, отже, величину витрат на заробітну плату ремонтного персоналу, що у свою чергу впливає на собівартість перевезень. Паливна економічність і ресурсомісткість визначають величину грошових витрат на паливо, мастильні та інші експлуатаційні матеріали, ремонт автомобільних шин, на запасні частини і матеріали. Ці витрати є статтями собівартості перевезень, а значить безпосередньо впливають на її величину.

Тип автомобіля визначає періодичність ТО і його трудомісткість, а отже впливає на величину простоїв і коефіцієнт технічної готовності. Надійність і експлуатаційна технологічність визначають кількість відмов і тривалість відновлення работоздатного стану, що також впливає на час вилучення автомобіля з лінії у разі відмови і відповідно на коефіцієнт технічної готовності.

Динамічність впливає на режими руху автомобіля 3 підсиленням яких знижується періодичність ТО і напрацювань на відмову, а значить знижується коефіцієнт технічної готовності. Із збільшенням ресурсоємності збільшується витрата запасних частин і трудомісткість ТО і ремонт. При цьому збільшується час очікування запасних частин і матеріалів, що призводить до збільшення простоїв в ТО і ремонті і знижується коефіцієнт технічної готовності.

Оскільки собівартість перевезень вимірюється в питомих одиницях до обсягу виконаної транспортної роботи (грн/ткм), то тип і надійність автомобіля, безпосередньо впливають на собівартість перевезень. Чим вища продуктивність на певному пробігу, тим нижча собівартість перевезень. Експлуатаційна технологічність визначає трудомісткість підтримку автомобілів в працездатному стані, а, отже, величину витрат на заробітну плату ремонтного персоналу, що у свою чергу впливає на собівартість перевезень. Паливна економічність і ресурсомісткість визначають величину грошових витрат на паливо, мастильні та інші експлуатаційні матеріали, ремонт автомобільних шин, на запасні частини і матеріали. Ці витрати є статтями собівартості перевезень, а значить безпосередньо впливають на $\dddot{1}$ величину.

Тип автомобіля визначає періодичність ТО і його трудомісткість, а отже впливає на величину простоїв і коефіцієнт технічної готовності. Надійність і експлуатаційна технологічність визначають кількість відмов і тривалість відновлення работоздатного стану, що також впливає на тривалість вилучення автомобіля з лінії у разі відмови і відповідно на коефіцієнт технічної готовності.

Динамічність впливає на режими руху автомобіля 3 підсиленням яких знижується періодичність ТО і напрацювань на відмову, а значить знижується коефіцієнт технічної готовності. Із збільшенням ресурсоємності збільшується витрата запасних частин і трудомісткість ТО і ремонт. При цьому збільшується час очікування запасних частин і матеріалів, що призводить до збільшення простоїв в ТО і ремонті і знижується коефіцієнт технічної готовності.

\section{ОБГОВОРЕННЯ РЕЗУЛЬТАТІВ ДОСЛІДЖЕННЯ}

Отже, такі ТЕВ, як швидкість руху, прохідність і надійність автомобіля визначаються конструктивними особливостями та умовами експлуатації або режимом використання конкретних 
марок РС. Коефіцієнт технічної готовності $\alpha_{T} €$ показником, за яким характеризуються такі властивості надійності, як: безвідмовність, ремонтопридатність і довговічність.

Встановлено, що між всіма ТЕВ $є$ взаємозв'язок і чітко відокремити їх не видається можливим. Так, якщо взяти такий показник як надійність, то він буде різним для кожного, оремо взятого, компонента автомобіля - неможливо зпрогнозувати в який саме період часу виникне несправність того чи іншого вузла або агрегата, при цьому не всі несправності призводять до повної зупинки автомобіля, отже, за таких умов, наприклад, технічна швидкість може змінюватися, а на останню, крім того, впливають дорожні умови, інтенсивність руху і т.д. Однозначно можна стверджувати, що між такими показниками ефективності експлуатації як продуктивність на певному пробігу i собівартість перевезень існує прямий зв'язок - чим вища продуктивність на певному пробігу, тим нижча собівартість перевезень і навпаки.

\section{ВИСНОВКИ}

Розглянуті ТЕВ можливо структурувати в наступні групи: тип автомобіля; надійність автомобіля; експлуатаційна технологічність; динамічність; стійкість; маневреність; прохідність; паливна економічність; ресурсоємність; легкість керування; комфортабельність.

Таким чином, проведений аналіз дозволив встановити вплив ТЕВ автомобілів на основні показники ефективності експлуатації (продуктивність вантажних автомобілів, собівартість перевезень, коефіцієнт технічної готовності).

Всі встановлені ТЕВ є необхідними для оцінки ефективності експлуатації автомобіля.

\section{ПЕРЕЛІК ДЖЕРЕЛ ПОСИЛАННЯ}

1. Бачурин А.А. Анализ производственно-хозяйственной деятельности автотранспортных организаций : учеб. пособие. Москва : Академия, 2004. 387 с.

2. Бычков В.П. Экономика автотранспортного предприятия : учебник. Москва : Инфра-М, 2006. $381 \mathrm{c}$.

3. Бочкарева М.М., Гудков В.А., Дулина Н.В. Количественная оценка качества транспортных услуг. Автотранспортное предприятие. Москва, 2007. №12. С. 49-53.

4. Пенынин Н.В. Эффективность и качество как фактор конкурентоспособности услуг на автомобильном транспорте : монография / под ред. В.П. Бычкова. Тамбов : Изд-во Тамб. гос. техн. ун-та, 2008. $224 \mathrm{c}$.

5. Мигачев В.А. Повышение эффективности использования грузовых автомобилей на основе выбора наиболее рационального парка подвижного состава : дис. ... канд. техн. наук: 05.22.10. Пенза, Ульяновск, 2012. $137 \mathrm{c}$.

6. Горев А.Э. Грузовые автомобильные перевозки : учеб. пособие. Москва : Изд. центр «Академия», 2004. 288 с.

7. Грузовые автомобильные перевозки : учебник / А.В. Вельможин и др. Москва : Горячая линия-Телеком, 2019. 560 с.

8. Хасанов Р.Х. Основы технической эксплуатации автомобилей : учеб. пособие. Оренбург : ГОУ ОГУ, 2003. 193 с.

9. Техническая эксплуатация автомобилей : учебник для вузов / Е.С. Кузнецов и др. Москва : Наука, 2001. 535 с.

\section{REFERENCES}

1. Bachurin A.A. (2004). Analysis of production and economic activities of motor transport organizations. [Analiz proizvodstvenno-hozjajstvennoj dejatelnosti avtotransportnyh organizacij. Uchebnoye posobiye] Moscow, Akademija Publ. 387 p.

2. Bychkov V.P. (2006). The economics of a trucking company. [Jekonomika avtotransportnogo predprijatija. Uchebnik] Moscow, Infra-M Publ. $381 \mathrm{p}$.

3. Bochkareva M.M., Gudkov V.A., Dulina N.V. (2007). Quantitative assessment of the quality of transport services. [Kolichestvennaja otsenka kachestva transportnyh uslug]. «Motor transport enterprise». No. 12, Moscow Publ. pp. 49-53.

4. Penynin N.V. (2008). Efficiency and quality as a factor in the competitiveness of road transport services. [Jeffektivnost i kachestvo kak faktor konkurentosposobnosti uslug na avtomobilnom transporte. Monografija] za red. V.P. Bychkov. Tambov, Tambov State Technical University Publ. 224 p.

5. Migachev V.A. (2012). Increasing the efficiency of the use of trucks based on the selection of the most rational fleet of rolling stock. Doct. Diss. [Povyshenie jeffektivnosti ispol'zovanija gruzovyh 
avtomobilej na osnove vybora naibolee racional'nogo parka podvizhnogo sostava. Dokt, Diss.] Penza, Uljanovsk. 137 p.

6. Gorev A.Je. (2004). Freight road transport. [Gruzovye avtomobilnye perevozki. Uchebnoye posobiye] Moscow, Akademija Publ. 288 p.

7. Velmozhin A.V., Gudkov V.A., Mirotin L.B., Kulikov A.V. (2019). Freight road transport. [Gruzovye avtomobilnye perevozki. Uchebnoye posobiye] Moscow, Gorjachaja linija-Telekom Publ. 560 p.

8. Khasanov R.Kh. (2003). Basics of technical operation of cars. [Osnovy tehnicheskoj jekspluatacii avtomobilej. Uchebnoye posobiye] Orenburg, Orenburg State University Publ. 193 p.

9. Technical maintenance of cars (2001). [Tehnicheskaja jekspluatacija avtomobilej. Uchebnik] E.S. Kuznetsov \& et al. Moscow, Nauka Publ. 535 p.

\section{indicators. \\ $V$. Khavruk. Influence of technical and operating properties of trucks on exploitation efficiency}

The paper considers complex indicators, which assess the efficiency of operation of rolling stock trucks: productivity, cost of transportation, the coefficient of technical readiness. It was found that productivity is determined over a period of time there are hourly, daily, monthly, quarterly, annual productivity. The given formulas for definition of annual productivity consider a design, idle time of the car in repairs and maintenance. Based on the analysis, it is established that the annual productivity of trucks depends on the technical and operational properties, which include two groups of parameters: 1) related to the design of the car (average technical speed, load capacity); 2) not related to the design of the car (the number of working days per year, the time the car is in gear per day, the average length of driving with the load, the mileage utilization rate). The influence of car carrying capacity on productivity is investigated and it is proved that productivity increases with increase of loading capacity of the car and decreases with increase in distance of driving with cargo. Based on the dependence of the cost of transporting cargo for dump trucks and general-purpose trucks, it is shown that with increasing load capacity of the car, the cost decreases. The expediency of using low-tonnage cars over short distances is substantiated, as under such conditions the processes of loading and unloading, maneuvering of cars are simplified, as a result the costs for fuels and lubricants, loading and unloading works are reduced. The analysis of this dependence allowed to establish that on short distances use of low-tonnage cars is more favorable as conditions of loading and unloading are simplified, maneuvering of cars is simplified, and consequently expenses for fuel, loading and unloading works decrease. But this dependence was obtained for specific operating conditions when organizing the work of vehicles on opencast development. The possibility of full use of the car's load capacity is characterized by the load capacity utilization factor. It is established that between productivity and capacity utilization factor there is a direct proportional dependence, thus, design features of the car are characterized by three operational properties: speed of movement, passability and reliability of the car. The dependence of the productivity of some trucks and the cost of transportation of goods on the average technical speed. The coefficient of technical readiness is rearranged as a comprehensive indicator that characterizes such reliability properties as: reliability, maintainability and durability and takes into account downtime in all types of maintenance and repairs. found that there is a directly proportional relationship between productivity on a certain mileage and the cost of transportation the higher the productivity, the lower the cost of transportation and vice versa.

Keywords: truck, coefficient of technical readiness, productivity, simple, rolling stock, cost of transportation, technical and operational properties.

ХАВРУК Володимир Олександрович, асистент кафедри технічної експлуатації автомобілів та автосервісу, Національний транспортний університет, e-mail: khavruk@gmail.com. http://orcid.org/0000-0002-4686-4109.

Volodymyr KHAVRUK, Assistant of Motor Vehicle Maintenance and Service Department, Kyiv National Transport University, e-mail: khavruk@gmail.com. http://orcid.org/0000-0002-4686-4109.

DOI 10.36910/automash.v1i16.519 